1 Delhi, India

2 London, UK

sal@sallyhoward.net

Cite this as: BMJ 2021;373:n1253

http://dx.doi.org/10.1136/bmj.n1253

Published: 19 May 2021

\title{
Covid-19: How India's doctors found their voice in the country's devastating second wave
}

\author{
Forced to step in and set up emergency clinics as hospitals fight legal battles for access to critical \\ supplies, many Indian doctors are turning to activism, write Geetanjali Krishna and Sally Howard
}

Geetanjali Krishna, ${ }^{1}$ Sally Howard ${ }^{2}$

Like many Indian doctors, Kafeel Khan says that he's long known about the country's lack of preparedness for covid-19.

In 2017, Khan blew the whistle on an oxygen supply scandal at BRD Medical College Hospital in Gorakhpur, a city in the state of Uttar Pradesh where he was then nodal officer in charge of the encephalitis ward. Seventy children and 18 adults died of asphyxiation at the hospital after its piped oxygen supply ran out. The hospital's lone supplier, based $270 \mathrm{~km}$ away in the state capital Lucknow, had cut supply because of the hospital's repeated failure to pay their bills. After speaking out about the scandal, Khan was suspended by Uttar Pradesh authorities on charges of medical negligence. It was two years before he was exonerated. ${ }^{1}$

Since the pandemic began, Khan has been a vocal campaigner for the need for large Indian hospitals to set up their own oxygen production units rather than being dependent on distant suppliers. "After a whole year, governments and hospitals should have realised the need to scale up their oxygen supply, but they didn't," says Khan. At the time of writing, India's official death toll from covid-19 is over 260 ooo, a figure thought to be an underestimate by a factor of up to $10 .^{2}$

Khan isn't alone. In a departure from their historically apolitical role, recent years have seen doctors across the country, both public and private, becoming vocal about injustices in healthcare, primarily the paucity of medical supplies, staffing, and administrative bungling. Their calls are often ignored. The year 2020 tipped them over the edge.

Harjit Singh Bhatti practises in a private hospital in Delhi. "Since last year we have been arguing that-given the inadequacies of our medical infrastructure-the only way to break the chain of SARS-CoV-2 transmission was by increased testing, contact tracing, and proper isolation protocols," he says, referring to warnings given to hospital administrators and in comments to the press. "Hospital capacities were not ramped up, hospital staff was not increased, and even oxygen supplies were not stocked," he says. Bhatti says his hospital's caseload has increased fivefold since March.

Siddhartth Taara, resident doctor and general secretary of the Resident Doctors Association, which represents the interests of junior doctors at Delhi's Hindu Rao Hospital, says there used to be two doctors for every five patients in their intensive care unit before the pandemic. "Today, ten critically ill patients are being treated by a single doctor,” he says.

The result is the brutal situation on the ground. The need for life-saving equipment is so great that "doctors actually wait for covid patients on ventilators to die," says Bhatti. "When they do, the precious ventilator is sterilised even before the body is taken away."

\section{Action in India's second wave}

Bhatti is national president of Progressive Medicos and Scientists Forum (PMSF), an independent group of doctors, researchers, and scientists who campaign against health injustices and provide emergency healthcare at pop-up field clinics at protest sites and areas affected by disasters. The group began in 2019 as doctors and interns at Delhi's All India Institute of Medical Sciences gathered informally to advocate for universal access to medicine.

But their role changed in February 2020 during the riots that came in the wake of the government's controversial India's Citizenship Amendment Act (the act fast tracked citizenship of immigrants who arrived in India before 2015 but appeared to discriminate against Muslims). PMSF stepped in to treat victims of the riots, with doctors paying for medical supplies out of their own pockets and providing medical care and first aid on the ground.

Later in the year, around 150 PMSF volunteers established voluntary clinics at the sites of farmer protests that began in September 2020 (in response to three farming acts that the government says are intended to increase farming incomes and productivity, but that farmers believe will harm their business). They started a social media hashtag, \#DoctorsForFarmers, to call attention to their solidarity with the protesters and to raise funds. As of April 2021, the protests are ongoing and the volunteers have organised 250 health camps.

All this came during the anxiety of the pandemic and one of the earliest and, at the time, harshest lockdowns in the world. But the adversity has seen many doctors take to action.

As the second wave tightens its grip, some have set up their own covid clinics to help ease the overloaded medical system. At the end of April, PMSF launched Doctors on the Road, a volunteer group who will set up clinics in rural areas where the already skeletal healthcare infrastructure has collapsed. In a similar, separate effort, Rahul Nagra, ${ }^{3}$ a retired doctor, has set up a clinic for the 200 residents of his Delhi 
housing condominium who have covid-19 but could not access medical care, equipped with personal protective equipment and oxygen purchased privately by another resident.

\section{Voices ignored}

Meanwhile, India's hospitals are fighting legal battles ${ }^{4}$ across the nation for crucial medical supplies, oxygen, and acceptable working conditions. ${ }^{5}$ As pandemic pressure escalates, so to do the number speaking out-often unheard, sometimes with consequences. The chief minister of Uttar Pradesh said as recently as 29 April 2021 that police could report individuals and hospitals complaining about the shortage of medical oxygen and beds to state authorities. ${ }^{6}$

Rajeev Jayadevan, deputy medical director at Sunrise Hospital in Kochi, Kerala, says that states where doctors have been listened to have fared better in the second wave. In Kerala, government medical colleges-which have emerged as the primary centres for treating covid-19 patients-established their own on-site oxygen production capacity following warnings from outspoken doctors about the dangers of supply shortages. State authorities also agreed to ban mass religious gatherings at doctors' recommendations.

According to Jayadevan, Kerala has seen only 15 doctors die from covid since the beginning of the pandemic (compared with 89 in neighbouring Tamil Nadu and 80 in West Bengal7). "Kerala had some things going for it in the covid battle-a literate population and an infrastructure of health visitors-but the fact that our doctors' words have been heeded has also helped," he says.

The Indian Medical Association (IMA), a national voluntary organisation of doctors, say the government requisitioned private hospitals in small towns to convert into covid-19 hospitals, even though they lacked the infrastructure or personnel to manage patients with the virus. It estimates that India's hospitals need at least $33 \%$ more doctors to replace staff members who have died, fallen ill, or burnt out.

According to IMA figures, the weeks from the 11 April to 4 May saw 126 doctor deaths across India, including those who have taken their own lives. ${ }^{8}$ The association says over 800 public facing doctors have lost their lives but exact numbers are difficult to ascertain. The central government does not count covid-19 deaths among healthcare workers, an oversight the IMA called a "gross indifference."

J A Jayalal, national president of the IMA, says that the fact doctors are increasingly emboldened to speak out is a "good sign that India is a democratic country," but that the government needs to acknowledge the pressures behind it, compensating the families of medical professionals who have died and allocating more government spending to healthcare. "We currently spend 1.5-2\% of gross domestic product on healthcare infrastructure. We need it to be $8-10 \%$," he says.

Jayalal says the association has campaigned for the wider rollout of vaccinations, priority approval of foreign made vaccines, and the improved supply and better use of oxygen in advance of this second wave.

There are some signs that the authorities are finally listening. On 15 April, the central government announced it had allocated emergency funds for oxygen generation plants to be set up within government hospitals across India, ${ }^{9}$ and allocated $\$ 400 \mathrm{~m}(£ 284 \mathrm{~m}$; $€_{329 \mathrm{~m})}$ to boost production at domestic vaccine producers the Serum Institute and Bharat Biotech. ${ }^{10}$ The government also opened up vaccination to all Indians over the age of $18^{11}$ and is in negotiations with the association to fast track the qualification of trainee doctors and nurses who have not taken their qualifying examinations because of the pandemic.

With India seeing over 400 ooo new covid infections a day at the time of writing, the reinforcements cannot come soon enough. But there are concerns about new trainees' readiness for the situation and whether the system can recruit as fast as it is losing workers.

Kafeel Khan says there's a "real possibility" the low morale experienced by Indian doctors during the pandemic will lead to medics leaving the profession or decamping to other countries. "This pandemic has exposed an already collapsed healthcare system,” he says.

Commissioned, not externally peer reviewed.

Competing interests: We have read and understood BMJ policy on declaration of interests and have no relevant interests to declare.

1 The Kafeel Khan story: how the exonerated Gorakhpur doctor spent the last 2 years. The Wire 28 September 2019. https://thewire.in/health/the-kafeel-khan-story-two-years-gorakhour-doctorexonerated.

2 Krishnan M. Coronavirus: Is India counting all covid deaths? DW 26 April 2021. www.dw.com/en/india-coronavirus-death-toll/a-57338733.

3 Wangchuk RN. “I set up a covid care facility”: man who couldn’t find hospital bed for dad. Better India. 26 April 2021. www.thebetterindia.com/253453/gurugram-covid19-care-facility-apartmentresidential-complex-free-coronavirus-treatment-oxygen-hospital-vishal-singh-delhi-ncr-indianor41.

$4 \quad$ Kalra A. 'Last resort': Desperate for oxygen, Indian hospitals go to court. Reuters. 5 May 2021. www.reuters.com/world/india/last-resort-desperate-oxygen-indian-hospitals-go-court-2021-05 04.

5 Banka R. Court asks Delhi government to arrange tankers for liquid oxygen amid shortage. Hindustan Times. 24 April 2021. www.hindustantimes.com/india-news/looking-at-big-humantragedy-3-hospitals-facing-oxygen-shortage-rush-to-delhi-hc-101619247130321.html.

6 Wallen J. Doctors threatened for blowing whistle on oxygen crisis as covid grips India. Telegraph 29 April 2021. www.telegraph.co.uk/news/2021/04/29/doctors-threatened-blowing-whistle-indiasoxygen-crisis.

$7 \quad$ Mascarenhas A. 747 doctors died of covid-19 in India: IMA. Indian Express. 17 April 2021. https://indianexpress.com/article/cities/pune/747-doctors-died-of-covid-19-in-india-ima-7277087.

8 Sengar MS. Doctor at top Delhi hospital's covid ward dies by suicide. NDTV. 2 May 2021. www.ndtv.com/india-news/doctor-working-in-covid-ward-of-delhi-hospital-for-1-month-commitssuicide-2426013.

9 Press Information Bureau Delhi. Government of India. 25 April 2021. https://pib.gov.in/PressReleseDetailm.aspx?PRID=1713904.

10 Ahmed A. India to fund capacity boost at Serum Institute, Bharat Biotech as vaccines run short Reuters. 20 April 2021 https://www.reuters.com/world/india/india-fund-capacity-boost-seruminstitute-vaccines-run-short-source-2021-04-19

11 Indian Ministry of Health and Family Welfare. Government of India announces a liberalised and accelerated phase 3 strategy of covid-19 vaccination from 1st May 19 April 2021. https://pib.gov.in/PressReleasePage.aspx?PRID=1712710. 